Research Article

\title{
Study on Cracking Resistance of Basalt Fiber-Reinforced Microbond Asphalt Macadam
}

\author{
Xin Yan, ${ }^{1}$ Ronghua Ying, ${ }^{1}$ Jian Jin, ${ }^{1}$ and Yuntai Zhang $\mathbb{D}^{2}$ \\ ${ }^{1}$ School of Traffic \& Transportation Engineering, Changsha University of Science \& Technology, Changsha 410114, China \\ ${ }^{2}$ School of Civil Engineering, Central South University, Changsha 410075, China \\ Correspondence should be addressed to Yuntai Zhang; zhangyuntai@csu.edu.cn
}

Received 18 November 2020; Revised 25 November 2020; Accepted 21 January 2021; Published 23 February 2021

Academic Editor: Arnaud Perrot

Copyright $(02021$ Xin Yan et al. This is an open access article distributed under the Creative Commons Attribution License, which permits unrestricted use, distribution, and reproduction in any medium, provided the original work is properly cited.

\begin{abstract}
The aim of the present study was to explore the effect of basalt fibers on the cracking resistance of microbond asphalt macadam and reduce the occurrence of cracks in asphalt pavements with semirigid base. To this end, compressive resilient modulus tests, rutting tests, and semicircular bending tests were conducted on microbond asphalt macadam with different fiber contents, and the change trends of the compressive resilient modulus, dynamic stability, and flexibility index (FI) with fiber content were revealed. According to the results of this study, the addition of basalt fibers affected the compressive resilient modulus, dynamic stability, and FI of microbond asphalt macadam significantly. With the increase of fiber content, the compressive resilient modulus, dynamic stability, and FI presented a uniform trend of increasing first and decreasing afterwards. When the fiber content was $0.4 \%$, various indices reached their maximum values, suggesting that the cracking resistance of the basalt fiber-reinforced microbond asphalt macadam was optimal under this content. This study is of great significance for the application and promotion of basalt fiber-reinforced microbond asphalt macadam.
\end{abstract}

\section{Introduction}

The development of China's highways mainly began in the mid-1980s. The economy has developed rapidly in recent years, highways have developed to a certain scale. Up to now, China's highway mileage has reached 150,000 kilometers. Semirigid base materials are applied on most high-grade highways in China, due to their high rigidity, strength, and diffusion-induced stress [1-3]. However, cracks of different sizes emerge in the early service period of pavements, the size and number of which tend to grow gradually with the increase of service time, resulting in the deterioration of the pavement status [4]. This is due to the fact that the dry- and temperature-shrinkage characteristics of the materials make the semirigid base susceptible to cracking under the combined actions of temperature, load, and other external factors. Gradually, cracks extend to the surface course, forming reflection cracks and damaging the integrity of the pavement structures [5]. Consequently, reflection cracks and their effects are notoriously tricky problems that cannot be ignored in the design and construction of semirigid base asphalt pavements. Currently, the solution of the reflection crack problem in semirigid base asphalt pavements constitutes a research hotspot in the field of road engineering [6-9].

To prevent the occurrence of cracks in asphalt pavements, related studies have been conducted by scholars both at home and abroad [10-13]. Some scholars paved an intermediate course of grading macadam between the subbase and surface courses, aiming to inhibit the occurrence of cracks and prolong the service life of semirigid base asphalt pavements. However, grading macadam has some apparent defects. First, due to the absence of cementing materials, it has low strength and weak load resistance and is vulnerable to rutting, permanent deformation, net-shaped cracks, and other damage. Second, it is very loose and poses difficulties to rolling in construction. In order to improve the strength and load resistance of grading macadam material, a kind of microbond asphalt macadam is proposed as an antireflection material. It has better construction performance and the modulus of grading macadam is increased to enhance its load 
resistance and antireflection capability. Li et al. [14] added a small number of asphalt cementing materials into the grading macadam, used microbond asphalt macadam with a certain thickness as the intermediate course of the pavement structure, and gave due consideration to the lower surface course. As a result, both the strength and load resistance of the grading macadam were improved, and the occurrence of cracks was inhibited to some extent. Wang et al. [15] studied the microbonding bituminous macadam material transition of semirigid base asphalt pavement, the aggregate gradation type influence on microbonding bituminous macadam material performance, and drawing the conclusion, and the grading macadam at the grass-roots level on the G-A-5 material gradation value in the scope of the antirutting performance is better than that of using AM grading of antirutting performance of the value of the material. Its cracking resistance is also better than that of the materials with AM grading. However, those methods presented also some problems. It was found that when consideration was given to the lower surface course in the use of existing microbond asphalt macadam materials, rutting and other defects would occur, seriously hindering the application and promotion of microbond asphalt macadam. This means that it is necessary to further enhance the cracking resistance of microbond macadam materials. This is where basalt fibers come into play since they are characterized by high tensile strength and resistance to low and high temperatures and corrosion [16-19]. Wang et al. [20] investigated the effect of basalt fibers on the properties of asphalt concrete. They found that adding basalt fibers could significantly improve the hightemperature deformation resistance and cracking resistance of the asphalt concrete and that the optimal performance was achieved under a fiber content of $0.5 \%$. So far, existing domestic studies have mainly focused on the effect of basalt fibers on the properties of asphalt concrete but rarely touch upon basalt fiber-modified microbond asphalt macadam. To answer the question whether basalt fibers can improve the cracking resistance of microbond asphalt macadam, further research is required [21].

In view of the above problems and the performance defects of existing microbond asphalt macadam materials, this study designed a novel basalt fiber-reinforced microbond asphalt macadam material. By taking this novel material as the research object, compressive resilient modulus tests, rutting tests, and semicircular bending tests under different fiber contents were conducted to reveal the change trends of its modulus, high-temperature deformation resistance, and cracking resistance. The crack resistance of the intermediate layer of basalt fiber microbonded asphalt gravel is evaluated. The results of this study provide some reference for the anticracking design of basalt fiber-reinforced microbond asphalt macadam and a method to solve the reflection crack of semirigid base pavement.

\section{Raw Material Selection}

In this study, grade-A 70\# paving asphalt developed by PetroChina was used. The coarse and fine aggregates were limestones produced by Yangjiaqiao Macadam Court. The fibers, which were $12 \mathrm{~mm}$ in length, were basalt fibers manufactured by Changsha Fibers Hi-tech Co., Ltd. (Figure 1). Relevant technical properties of the raw materials used are presented in Tables 1-4 .

According to Tables 1-4, the technical properties of all materials conform to the requirements of relevant codes and can be used for related performance tests on basalt fiberreinforced microbond asphalt macadam.

\section{Mix Design and Specimen Preparation}

3.1. Gradation Selection. The gradation type selected in this study was the gradation median of the gradation range of G-A-5 grading macadam for the upper base, which is recommended in the Specifications for Design of Highway Asphalt Pavement (JTG D50-2017) [22] (Table 5).

\subsection{Determination of Minimum and Maximum Asphalt} Content. To ensure that the material could reach a certain strength without becoming loose due to a low asphalt content, specimens were molded using asphalt contents of $1.5 \%, 2.0 \%$, and $2.5 \%$. It was observed that, under an asphalt content of $2.0 \%$, the specimens were well molded with only a little aggregate shedding, while, under an asphalt content of $2.5 \%$, the specimens were fully molded. However, due to the strong subjectivity of the coating test, the results can only serve as a reference. Cold-patch mixture cohesiveness tests were employed according to the Technical Specification for Construction of Highway Asphalt Pavements (JTG F402004) to evaluate the cohesiveness of the fiber-reinforced asphalt mixtures [23]. On the basis of the asphalt contents of $2.0 \%$ and $2.5 \%$, specimens were molded using six different asphalt contents $(2.1 \%, 2.2 \%, 2.3 \%, 2.4 \%, 2.5 \%$, and $2.6 \%)$, followed by the cohesiveness test. The minimum asphalt contents corresponding to the specimens with fiber contents of $0 \%, 0.2 \%, 0.4 \%$, and $0.6 \%$ were $2.2 \%, 2.3 \%, 2.4 \%$, and $2.5 \%$, respectively. The specific test results are shown in Figure 2:

To ensure adequate aggregate coating, drain-down tests were carried out to determine the maximum asphalt content, and mixtures were prepared under five different asphalt contents $(2.8 \%, 3.0 \%, 3.2 \%, 3.4 \%$, and $3.6 \%)$. Referring to the practice of Germany and Japan [24], enamel basins were used in the tests. In the drain-down tests, the mass loss rate of $0.5 \%$ corresponded to the maximum asphalt content [25]. As it can be seen by the test results in Figure 3, the maximum asphalt contents of the mixtures with fiber contents of $0 \%$, $0.2 \%, 0.4 \%$, and $0.6 \%$ were $3.2 \%, 3.3 \%, 3.4 \%$, and $3.4 \%$, respectively.

3.3. Determination of Optimal Asphalt Content. It has been shown [26] that the Marshall test cannot be employed for the determination of the optimal asphalt content of microbond asphalt macadam, mainly due to the low content, unstable fluidity, and irregularity of the asphalt. In this case, indices can be designed with reference to the composition of the grading macadam, in order to determine the optimal asphalt 


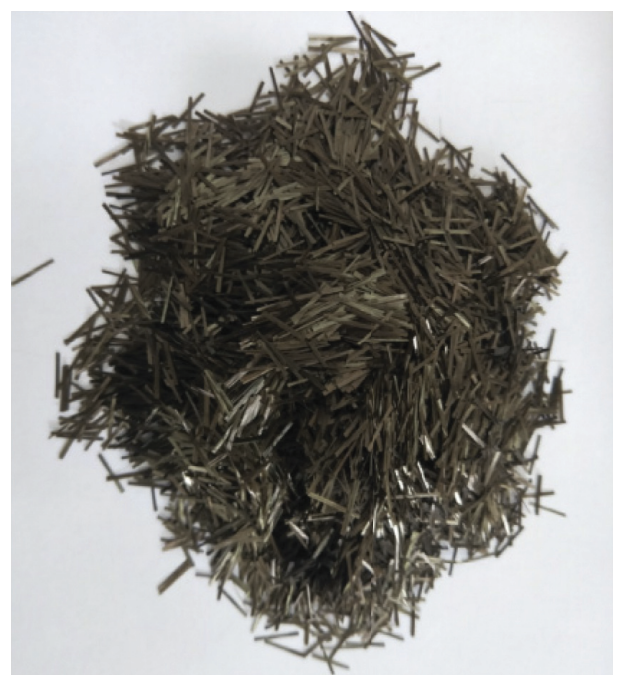

FIgURE 1: Basalt fibers.

TABLE 1: Technical indices of asphalt.

\begin{tabular}{lcccc}
\hline Test item & Unit & Test result & Code requirement & Test method \\
\hline Penetration $\left(25^{\circ} \mathrm{C}, 5 \mathrm{~s}, 100 \mathrm{~g}\right)$ & $0.1 \mathrm{~mm}$ & 74 & $60 \sim 80$ & T0604 \\
Penetration index, PI & - & 0.034 & $-1.5 \sim 1.0$ & T0604 \\
Softening point & ${ }^{\circ} \mathrm{C}$ & 52.3 & $\geq 45$ & T0606 \\
Ductility at $15^{\circ} \mathrm{C}$ & $\mathrm{cm}$ & 127 & $\geq 100$ & $\mathrm{~T} 0605$ \\
Flash point & ${ }^{\circ} \mathrm{C}$ & 300 & $\geq 260$ & $\mathrm{~T} 0611$ \\
Solubility & $\%$ & 98.8 & $\geq 99.5$ & $\mathrm{~T} 0607$ \\
Relative density & - & 1.036 & - & T0603 \\
\hline
\end{tabular}

TAвle 2: Physical and mechanical indices of coarse aggregates with different particle sizes.

\begin{tabular}{|c|c|c|c|c|c|c|c|}
\hline \multirow{2}{*}{ Number } & \multirow{2}{*}{ Test item } & \multirow{2}{*}{ Standard value } & \multicolumn{4}{|c|}{ Test results of coarse aggregates } & \multirow{2}{*}{ Test method } \\
\hline & & & $15 \sim 25 \mathrm{~mm}$ & $10 \sim 15 \mathrm{~mm}$ & $5 \sim 10 \mathrm{~mm}$ & $3 \sim 5 \mathrm{~mm}$ & \\
\hline 1 & Crushing strength (\%) & $\leq 26$ & - & 15.8 & - & - & T0316 \\
\hline 2 & Apparent relative gravity $\left(\mathrm{g} / \mathrm{cm}^{3}\right)$ & $\geq 2.5$ & 2.742 & 2.721 & 2.734 & 2.752 & T0304 \\
\hline 3 & Bulk volume density $\left(\mathrm{g} / \mathrm{cm}^{3}\right)$ & Measured & 2.673 & 2.724 & 2.687 & 2.636 & T0304 \\
\hline 4 & Water absorption rate (\%) & $\leq 3.0$ & 2.02 & 2.08 & 2.31 & 2.42 & T0310 \\
\hline 5 & Los Angeles abrasion value (\%) & $\leq 28$ & 11 & 13.3 & 14.3 & - & T0320 \\
\hline 6 & Asphalt adhesion grade & $\geq 4$ & 4 & - & - & - & T0616 \\
\hline
\end{tabular}

Table 3: Physical and mechanical indices of fine aggregate $(0 \sim 3 \mathrm{~mm})$.

\begin{tabular}{lcccc}
\hline Number & Test item & Technical requirement & Test results of fine aggregate & Test method \\
\hline 1 & Apparent density $\left(\mathrm{g} / \mathrm{cm}^{3}\right)$ & $\geq 2.5$ & 2.731 & T0328 \\
2 & Sand equivalent $(\%)$ & $\geq 50$ & 59 & T0340 \\
3 & Mud equivalent $(\%)$ & $\leq 4$ & 2.1 & T0349 \\
\hline
\end{tabular}

Table 4: Performance indices and test results of basalt fibers.

\begin{tabular}{lcc}
\hline Test item & Technical requirement & Measured value \\
\hline Breaking strength $(\mathrm{MPa})$ & $\geq 1,500$ & 2325 \\
Elongation at break (\%) & $\leq 3.1$ & 2.58 \\
Oil absorption rate (\%) & $\geq 50$ & 51.1 \\
Combustible content (\%) & $0.1 \sim 1.0$ & 0.5 \\
Water content (\%) & $\leq 0.2$ & 0.08 \\
Heat resistance-break strength retention (\%) & $\geq 85$ & 92 \\
\hline
\end{tabular}

The heat resistance is defined as the break strength retention after $4 \mathrm{~h}$ of continuous heating in an oven at $250^{\circ} \mathrm{C}$. 
TABLE 5: Gradation range of G-A-5 grading macadam for the upper base.

\begin{tabular}{|c|c|c|c|c|c|c|c|c|c|c|c|c|}
\hline \multirow{2}{*}{ Sieve mesh (mm) } & \multicolumn{12}{|c|}{ Passing percentage (\%) } \\
\hline & 26.5 & 19 & 16 & 13.2 & 9.5 & 4.75 & 2.36 & 1.18 & 0.6 & 0.3 & 0.15 & 0.075 \\
\hline Upper limit & 100 & 100 & 89 & 79 & 63 & 40 & 28 & 20 & 14 & 10 & 7 & 5 \\
\hline Lower limit & 100 & 95 & 82 & 70 & 53 & 30 & 19 & 12 & 8 & 5 & 3 & 2 \\
\hline Gradation median & 100 & 97.5 & 85.5 & 74.5 & 58 & 35 & 23.5 & 16 & 11 & 7.5 & 5 & 3.5 \\
\hline
\end{tabular}

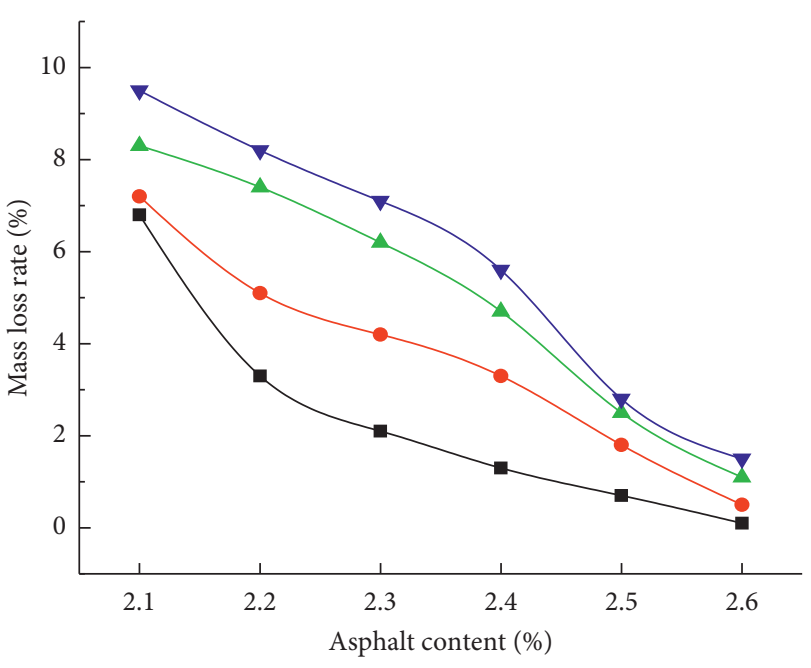

Fiber content (\%)

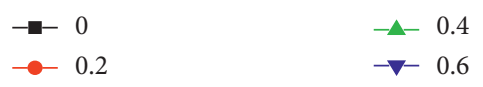

FIgURE 2: Mass loss rate.

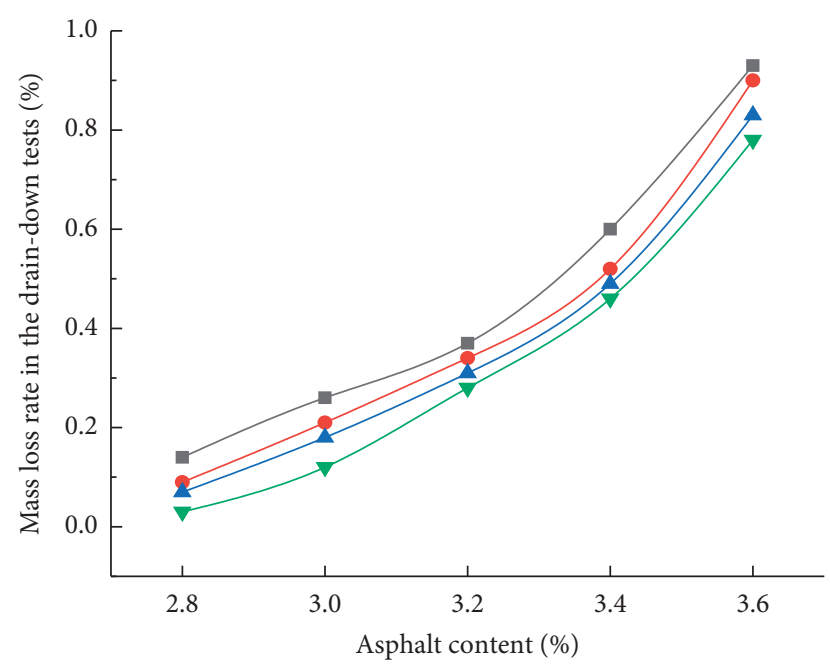

Fiber content (\%)

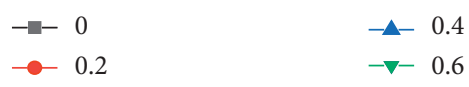

Figure 3: Mass loss rate in the drain-down tests.

content of microbond asphalt macadam using bearing ratio tests. The California bearing ratio (CBR) index can reflect the ability of basalt fiber-reinforced microbond asphalt macadam as the intermediate course material to withstand deformation. When CBR reaches its peak value, the corresponding asphalt content can be adopted as the optimal asphalt content [27].

3.3.1. Void Percentage. The compactness of a material is affected by a variety of factors. In this study, research was conducted from the perspective of material factors, and the wax sealing method was introduced to investigate the changing effects of the asphalt and fiber contents on the void percentage of the microbond asphalt macadam [28]. The specific test results are shown in Figure 4.

According to Figure 4, given the fiber content, the void percentage of the specimen would gradually decrease with the increase of the asphalt content and vary within the range of $9 \%-18 \%$. The above results meet the technical requirements for microbond asphalt macadam stipulated in the specifications.

3.3.2. Bearing Ratio Test. The bearing ratios were determined using the uniaxial penetration method described in the Standard Test Methods of Bitumen and Bituminous Mixtures for Highway Engineering (T0713-2017). The specimens, which were standard Marshall Specimens, were molded according to the typical compacting method. The testing instrument was a pressing machine.

Change trends of the specimen CBR under different fiber and asphalt contents. The test results are summarized in Table 6 and Figure 5:

For the microbond asphalt macadam specimens prepared with four different fiber contents, given the fiber content, the CBR increased first and then decreased with increasing asphalt content. In all these cases, peaks emerged and their change trends were roughly the same. The asphalt content corresponding to the CBR peak was determined as the optimal asphalt content. The results are summarized in Table 7.

3.4. Specimen Preparation. In this study, the cracking resistance of microbond asphalt macadam with four different fiber contents $(0,0.2 \%, 0.4 \%$, and $0.6 \%$, calculated by mass) was investigated according to relevant test codes and specifications. Molding was performed at around $160^{\circ} \mathrm{C}$. The cylindrical specimens used in the compressive resilient modulus tests were $100 \mathrm{~mm}$ in diameter and height, and they were obtained through static molding. Four parallel specimens were prepared. The specimens used in the rutting tests were $100 \mathrm{~mm} \times 100 \mathrm{~mm} \times 50 \mathrm{~mm}$ in size (length $\times$ width $\times$ height). They were molded using the wheel rolling method and prepared with three parallel specimens. The semicircular 


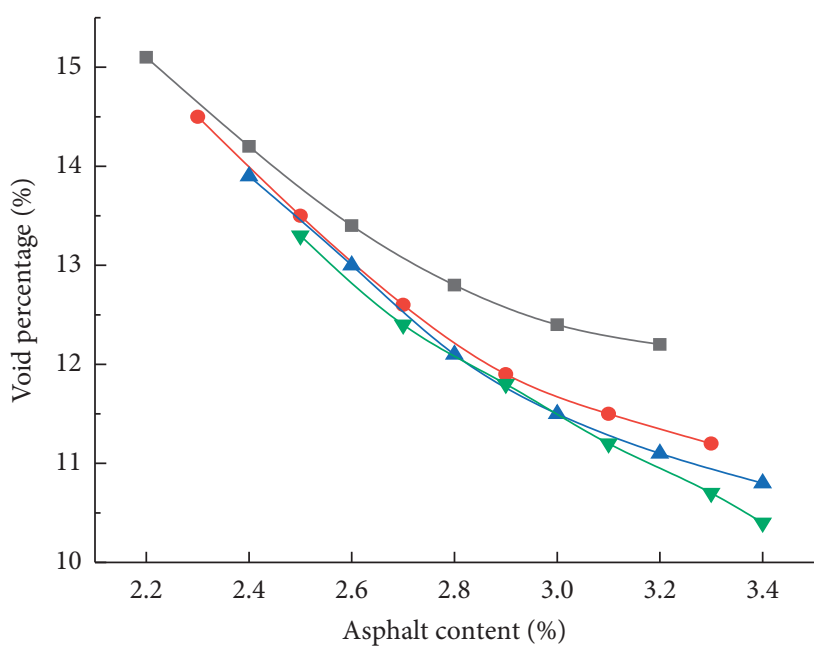

Fiber content (\%)

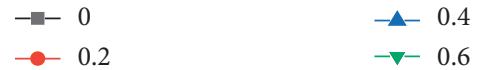

Figure 4: Void percentage.

TABLE 6: CBR values of specimens with different fiber contents.

\begin{tabular}{lccccccc}
\hline $\begin{array}{l}\text { 0\% basalt } \\
\text { fiber content }\end{array}$ & $\begin{array}{c}\text { Asphalt } \\
\text { content (\%) } \\
\text { CBR (\%) }\end{array}$ & $2.2 \%$ & $2.4 \%$ & $2.6 \%$ & $2.8 \%$ & $3.0 \%$ & $3.2 \%$ \\
\hline $\begin{array}{l}\text { 0.2\% basalt } \\
\text { fiber content }\end{array}$ & $\begin{array}{c}\text { Asphalt } \\
\text { content (\%) } \\
\text { CBR (\%) }\end{array}$ & $2.3 \%$ & $2.5 \%$ & $2.7 \%$ & $2.9 \%$ & $3.1 \%$ & $3.3 \%$ \\
\hline $\begin{array}{l}\text { 0.4\% basalt } \\
\text { fiber content }\end{array}$ & $\begin{array}{c}\text { Asphalt } \\
\text { content (\%) } \\
\text { CBR (\%) }\end{array}$ & $2.4 \%$ & $2.6 \%$ & 212 & 208 & 196 & 186 \\
\hline $\begin{array}{l}\text { 0.6\% basalt } \\
\text { fiber content }\end{array}$ & $\begin{array}{c}\text { Asphalt } \\
\text { content (\%) } \\
\text { CBR (\%) }\end{array}$ & $2.5 \%$ & $2.7 \%$ & $2.9 \%$ & $2.0 \%$ & $3.2 \%$ & $3.4 \%$ \\
\hline
\end{tabular}

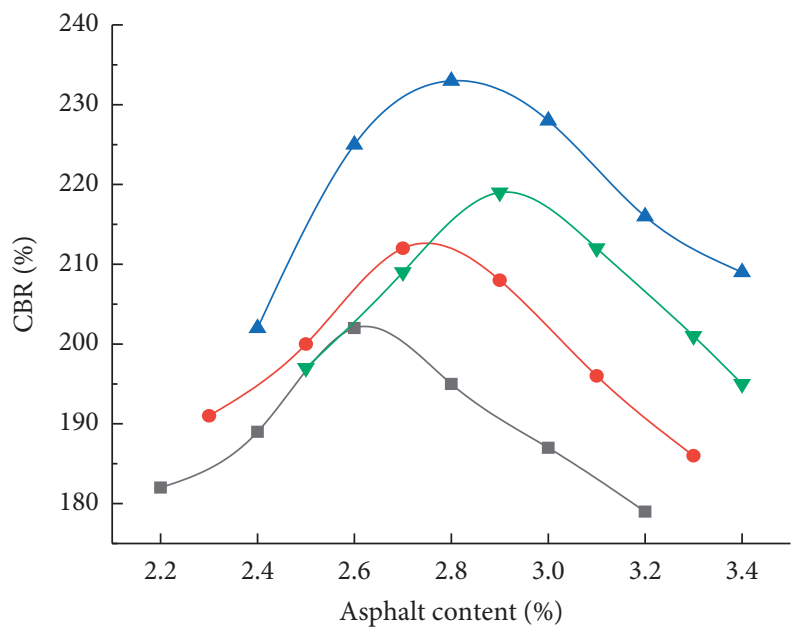

Fiber content (\%)

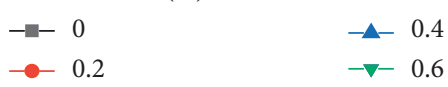

Figure 5: Relationship between CBR and fiber content.
TABLE 7: Optimal asphalt content of microbond asphalt macadam for different fiber contents.

\begin{tabular}{lcccc}
\hline Fiber content (\%) & 0 & 0.2 & 0.4 & 0.6 \\
\hline Optimal asphalt content (\%) & 2.6 & 2.7 & 2.8 & 2.9 \\
\hline
\end{tabular}

specimens used in the semicircular bending tests were $101.6 \mathrm{~mm}$ in diameter and $50 \mathrm{~mm}$ in height. They were designed with a $1.5 \mathrm{~cm}$ kerf at the bottom, molded according to the typical compacting method, and prepared with three parallel specimens.

\section{Pavement Performance Test on Microbond Asphalt Macadam}

As the intermediate course, basalt fiber-reinforced microbond asphalt macadam must have adequate strength and modulus of elasticity and sound high-temperature stability and cracking resistance [29]. Thus, it is necessary to verify its pavement performance and propose an evaluation method.

4.1. Compressive Resilient Modulus Test. In this study, the uniaxial compression test method described in the Standard Test Methods of Bitumen and Bituminous Mixtures for Highway Engineering (JTGE20-2011) was adopted. A Mechanical Testing and Simulation was used to perform the compressive resilient modulus tests at a loading rate of $2 \mathrm{~mm} / \mathrm{min}$ at $20^{\circ} \mathrm{C}$. Before testing, the specimens were placed in a thermostatic water bath $\left(20^{\circ} \mathrm{C}\right)$ for heat preservation for no less than $2.5 \mathrm{~h}$; during heat preservation, a minimum spacing of $10 \mathrm{~mm}$ between specimens was maintained. A cylindrical specimen was randomly selected to measure the compressive stress at specimen failure. The compressive strength of the basalt fiber-reinforced microbond asphalt macadam specimen can be calculated according to the following equation:

$$
R_{c}=\frac{4 P}{\pi d^{2}}
$$

where $R_{c}$ is compressive strength of the specimen (MPa); $P$ is maximum load at specimen failure $(\mathrm{N})$; and $d$ is specimen diameter $(\mathrm{mm})$.

The $q_{i}-\Delta_{L i}$ curve is plotted and intersects with the axes, thus producing the correction origin. The fifth-level load and the corresponding $\Delta_{L}$ are obtained from the curve based on the origin coordinates. The compressive resilient modulus is calculated according to the following equation:

$$
\begin{aligned}
& q_{i}=\frac{4 P_{i}}{\pi d^{2}}, \\
& E=\frac{q_{s} \times h}{\Delta L_{S}},
\end{aligned}
$$

where $q_{\mathrm{i}}$ is pressure under applied load $P_{i}, \mathrm{MPa} ; P_{i}$ is load applied on the specimen, $N ; E$ is compressive resilient modulus, $\mathrm{MPa} ; q_{s}$ is pressure under the fifth-level load (0.5 $\mathrm{P}), \mathrm{MPa} ; h$ is axis height of the specimen; and $\Delta_{L s}$ is rebound 
deformation corrected by the origin under the fifth-level load (0.5 P).

4.2. High-Temperature Rutting Test. Rutting tests are most commonly used for evaluating the high-temperature stability of asphalt mixtures [30]. As required by related test specifications, the test temperature was set at $60^{\circ} \mathrm{C}$, the reciprocating wheel pressure rate at $42 \pm 1$ times $/ \mathrm{min}$, and the wheel pressure at $0.7 \pm 0.05 \mathrm{MPa}$. A rutting test machine was used, and the dynamic stability of the specimens was calculated using $45 \mathrm{~min}$ and $60 \mathrm{~min}$ rutting deformation values calculated according to the following equation:

$$
D S=\frac{\left(t_{2}-t_{1}\right) \times N}{d_{2}-d_{1}} \times C_{1} \times C_{2},
$$

where $D S$ is dynamic stability, time/mm; $\mathrm{d}_{1}$ is deformation of the basalt fiber-reinforced microbond asphalt macadam specimen at rutting test time $t_{1}, \mathrm{~mm} ; d_{2}$ is deformation of the basalt fiber-reinforced microbond asphalt macadam specimen at rutting test time $t_{2}, \mathrm{~mm} ; C_{1}, C_{2}$ are test coefficients (based on the specimen preparation process for this test, $C_{1}=C_{2}=1.0$ ); and $N$ is reciprocating rolling rate, usually set as 42 times/min.

4.3. Cracking Test. Semicircular bending tests are often used to evaluate the cracking resistance of asphalt mixtures [31]. In this study, the tests were conducted using a universal testing machine at a loading rate of $50 \mathrm{~mm} / \mathrm{min}$ at $25^{\circ} \mathrm{C}$ until specimen failure. The work required to fracture the specimen completely (work of fracture $W_{f}$ ) can be determined from the area enclosed by the curve segment and the axes. The ratio of the work of fracture $W_{f}$ to the specimen ligament area denotes the fracture energy $G_{f}$, as shown by the following equations:

$$
\begin{aligned}
G_{f} & =\frac{W_{f}}{\text { Area }_{\text {lig }}} \times 10^{6} . \\
\text { area }_{\text {lig }} & =\text { length of tough zone } \times \mathrm{t},
\end{aligned}
$$

where $G_{f}$ is fracture energy $\left(J / \mathrm{m}^{2}\right) ; W_{f}$ is work of fracture $(J)$; Area $_{\text {lig }}$ is area of tough zone $\left(\mathrm{mm}^{2}\right)$; and $t$ is specimen thickness (mm).

Studies have demonstrated that the postpeak slope $|\mathrm{m}|$ and the flexibility index (FI) can reflect the anticrack propagation performance of asphalt mixtures. $|\mathrm{m}|$ refers to the postpeak point at $75 \%$ of the peak load and is closer to the knee of the curve [11], as shown by the following equation:

$$
F I=\frac{G_{f}}{|m|} \times A,
$$

where FI is the flexibility index; $|m|$ is the absolute value of postpeak slope $(\mathrm{kN} / \mathrm{mm})$; and $\mathrm{A}$ is unit conversion, equal to 0.01 .

\section{Test Results and Analysis}

5.1. Relationship between Compressive Resilient Modulus and Fiber Content. Molded specimens were tested using the uniaxial compression test method according to related test specifications. The uniaxial compression test results of microbond asphalt macadam specimens with different fiber contents are listed in Table 8.

As can be seen in Figure 6, when the fiber content increased within the range of $0-0.4 \%$, the compressive resilient modulus of the material increased as well. When the fiber content was $0.4 \%$, the compressive resilient modulus reached its peak value. When the fiber content exceeded $0.4 \%$, the compressive resilient modulus decreased to some extent. This is attributed to that a suitable fiber content in microbond asphalt macadam plays bridging and reinforcing roles and timely transmits and disperses loads, thus making the stress applied to the basalt fiber-reinforced microbond asphalt macadam more uniform. Above the threshold of $0.4 \%$, the distribution of fibers becomes less uniform, making the basalt fiber-reinforced microbond asphalt macadam prone to balling and resulting in a lower compressive resilient modulus.

\subsection{Effect of Fiber Content on High-Temperature Stability.} The tests were conducted according to the rutting test method described in the literature. The test results are listed in Table 9.

By analyzing the above rutting test results in Figure 7, the following can be found.

The dynamic stability of the specimens increased first and then decreased with increasing fiber content. Compared to an ordinary microbond asphalt macadam specimen, the dynamic stability of specimens with basalt fiber contents of $0.2 \%, 0.4 \%$, and $0.6 \%$ increased by $14.8 \%, 26.7 \%$, and $25.3 \%$, respectively. This suggests that the addition of basalt fibers improved the high-temperature stability of microbond asphalt macadam, while the peak dynamic stability and optimal high-temperature stability was achieved when the fiber content was $0.4 \%$.

5.3. Cracking Test. The cracking tests were carried out according to the semicircular bending test method described in the literature. The test results are listed in Table 10.

Effect of fiber content on the crack propagation performance of microbond asphalt macadam.

According to the comparison between Table 10 and Figures 8 and 9 , when the fiber content fell within the range of $0 \sim 0.4 \%$, the work of fracture Wf and fracture energy Gf of the specimens were both positively correlated with fiber content. When the fiber content was $0.4 \%$, both the work of fracture Wf and fracture energy Gf exhibited a peak and were increased by $29.7 \%$ compared to those of an ordinary microbond asphalt macadam. When the fiber content was further increased, the work of fracture Wf and fracture 
TABLE 8: Uniaxial compression test results.

\begin{tabular}{lcc}
\hline Fiber content $(\%)$ & $E_{\mathrm{c}}(\mathrm{MPa})$ & $E_{\mathrm{c}}(\mathrm{MPa})$ \\
\hline 0 & $335,334,331,340$ & 335 \\
0.2 & $401,404,398,413$ & 404 \\
0.4 & $491,495,499,499$ & 496 \\
0.6 & $472,475,483,474$ & 476 \\
\hline
\end{tabular}

$E_{\mathrm{c}}$ is the compressive resilient modulus and $E_{\mathrm{c}}$ is the mean compressive resilient modulus.

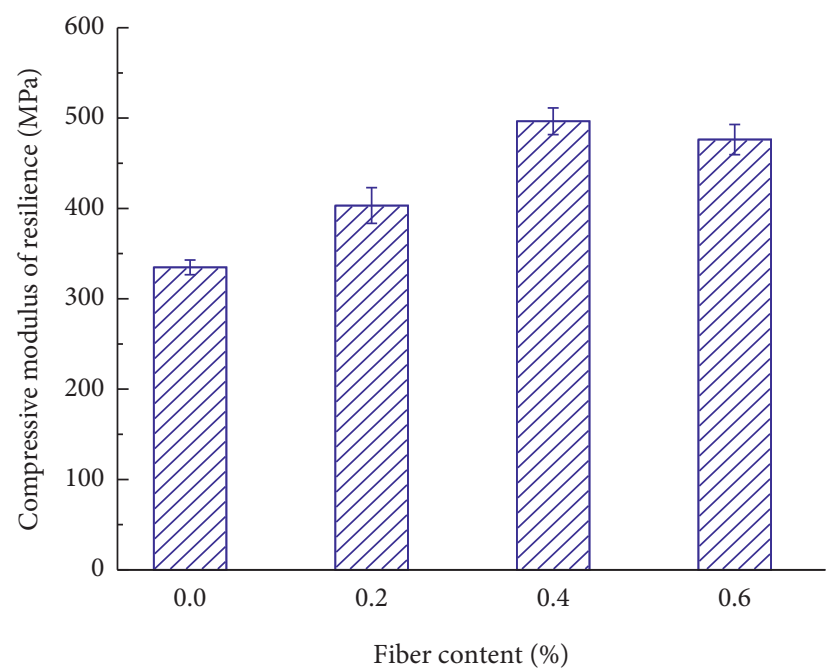

FIGURE 6: Relationship between compressive resilient modulus and fiber content.

TABLE 9: Rutting test results on microbond asphalt macadam specimens with different basalt fiber contents.

\begin{tabular}{lccc}
\hline $\begin{array}{l}\text { Fiber } \\
\text { content (\%) }\end{array}$ & $\begin{array}{c}\text { Optimal asphalt } \\
\text { content (\%) }\end{array}$ & $\begin{array}{c}\text { DS } \\
\text { (time/min) }\end{array}$ & $\begin{array}{c}\overline{D S} \\
\text { (time/min) }\end{array}$ \\
\hline 0 & 2.7 & $2,061,2,072,2,053$ & 2,062 \\
0.2 & 2.8 & $2,378,2,371,2,355$ & 2,368 \\
0.4 & 2.9 & $2,611,2,623,2,602$ & 2,612 \\
0.6 & 3.0 & $2,576,2,583,2,593$ & 2,584 \\
\hline
\end{tabular}

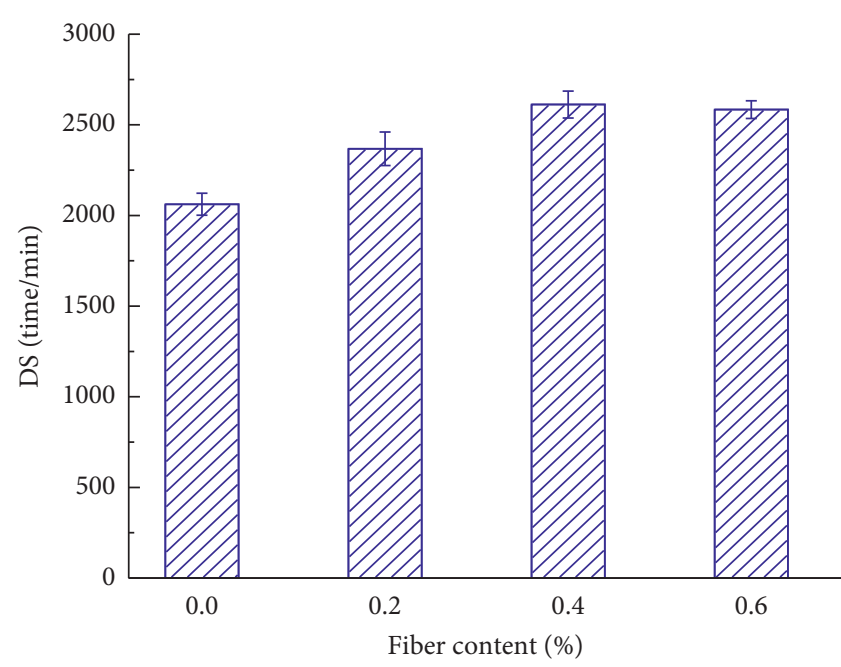

FIGURE 7: Effect of fiber content on dynamic stability.
TABLE 10: Semicircular bending test results of microbond asphalt macadam with different fiber contents.

\begin{tabular}{lcccc}
\hline Fiber content $(\%)$ & $W_{\mathrm{f}}(j)$ & $G_{\mathrm{f}}\left(j / \mathrm{m}^{2}\right)$ & $|m|$ & FI \\
\hline \multirow{3}{*}{0} & 7.75, & $4,428.57$, & 1.145, & 38.68, \\
& 7.48, & $4,274.29$, & 1.152, & 37.10, \\
& 7.89 & $4,508.57$ & 1.149 & 39.24 \\
\hline \multirow{3}{*}{0.2} & 8.93, & $5,102.86$, & 1.022, & 49.93, \\
& 9.22, & $5,268.57$, & 1.016, & 51.85, \\
0.4 & 9.37 & $5,354.28$ & 1.014 & 52.80 \\
\hline \multirow{3}{*}{0.6} & 10.35, & $5,914.29$, & 0.938, & 63.05, \\
& 10.13, & $5,788.57$, & 0.943, & 61.39, \\
& 10.55 & $6,028.57$ & 0.936 & 64.40 \\
\hline
\end{tabular}

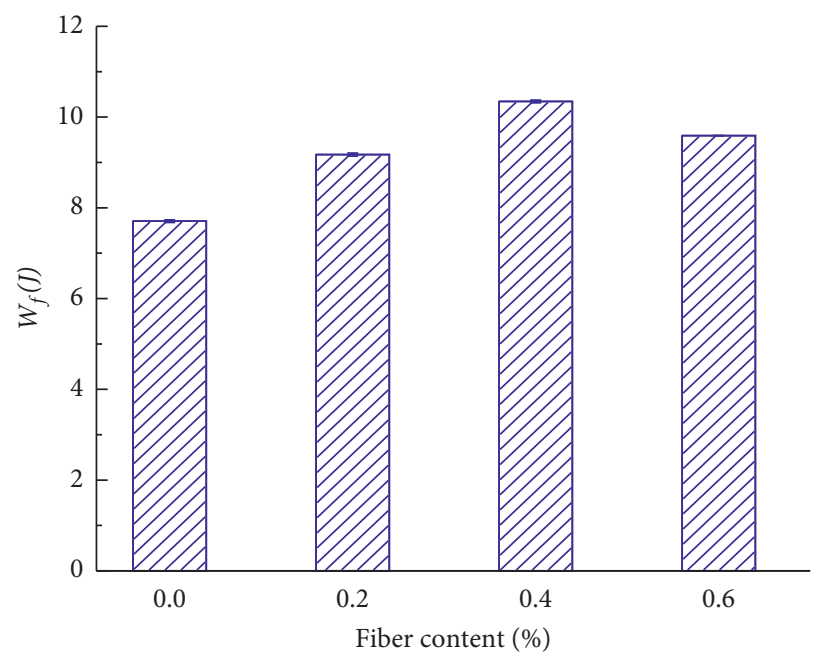

FIgURE 8: Work of fracture $W_{f}$ versus fiber content.

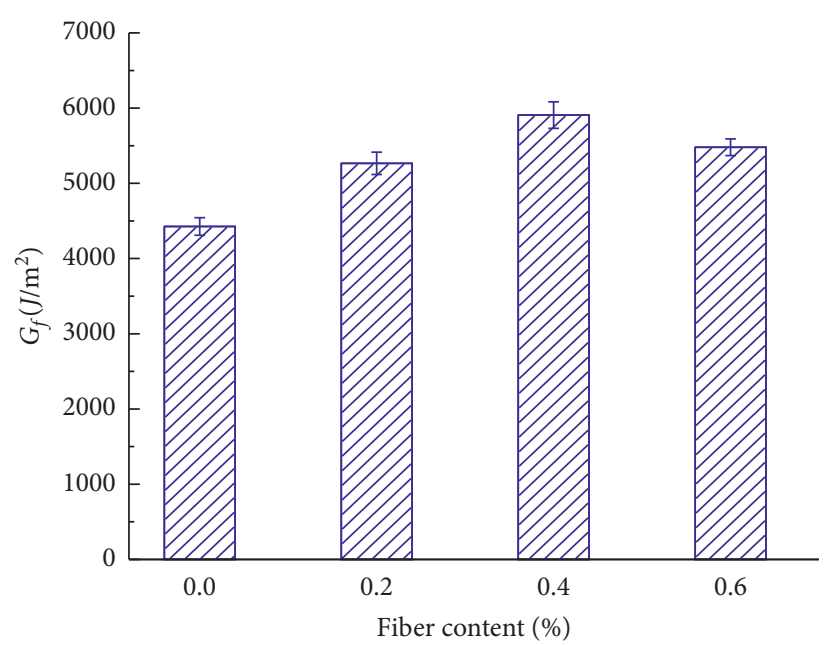

Figure 9: Fracture energy $G_{f}$ versus fiber content.

energy Gf decreased, suggesting that more work would be required to fracture the specimen with a fiber content of $0.4 \%$. Table 10, Figure 10, and Figure 11 revealed that the 


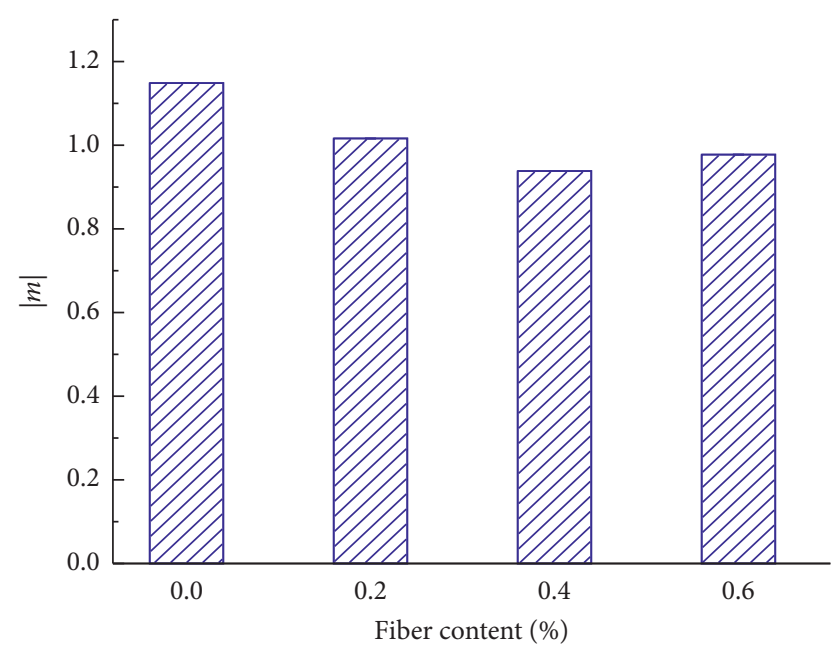

FIgURE 10: Slope versus fiber content.

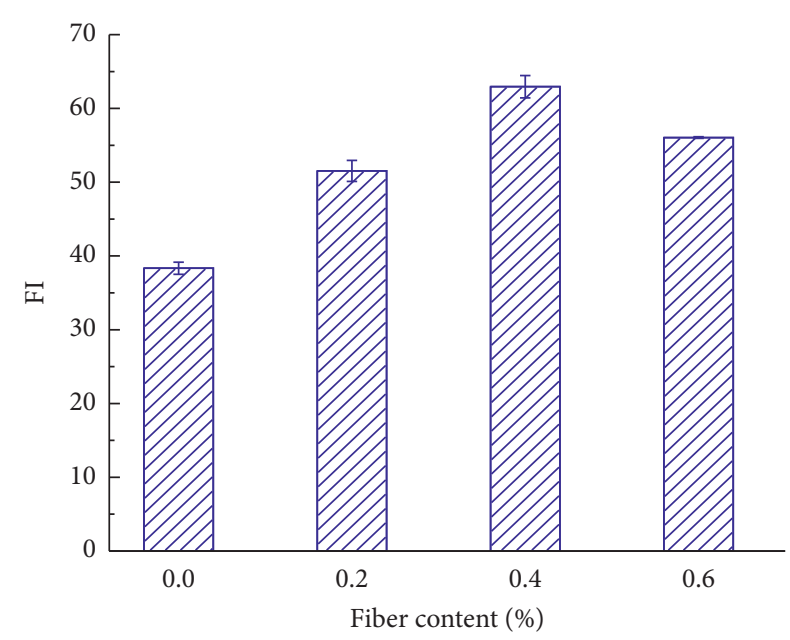

FIgURE 11: FI versus fiber content.

specimen postpeak slope $|\mathrm{m}|$ reached its minimum value when the fiber content was $0.4 \%$ and that the specimen FI also reached its maximum value when the fiber content was $0.4 \%$; an improvement of $57.1 \%$ compared to those of an ordinary microbond asphalt macadam. This suggested that the fiber content of $0.4 \%$ was the most effective in slowing crack propagation; that is, it provided a microbond asphalt macadam with optimal cracking resistance.

\section{Conclusions}

This study mainly investigated the high-temperature stability and cracking resistance of basalt fiber-reinforced microbond asphalt macadam and analyzed the effects of fiber content on the compressive resilient modulus, dynamic stability, and flexibility index (FI). The conclusions are drawn as follows:

(1) The compressive resilient modulus, high-temperature rutting resistance, and cracking resistance of basalt fiber-reinforced microbond asphalt macadam were significantly affected by the basalt fiber content. In particular, they increased first and then decreased with increasing fiber content. This was mainly due to the fact that, under a high fiber content, the uniform distribution of the fibers was compromised, making the structure prone to agglomeration phenomena such as balling. As a result, the compressive resilient modulus, dynamic stability, and flexibility index (FI) presented a decreasing trend.

(2) The optimal fiber content for basalt fiber-reinforced microbond asphalt macadam was $0.4 \%$. Compared to an ordinary microbond asphalt macadam, the cracking resistance of the basalt fiber-reinforced microbond asphalt macadam exhibited an improvement of $57.1 \%$.

(3) In addition, while this study investigated the effect of fiber content on compressive resilient modulus, high-temperature stability, and cracking resistance, it did not take into account the effect of the gradation type of mineral aggregates on their cracking resistance. Considering the highly significant effects of gradation type on compressive resilient modulus, high-temperature stability, and cracking resistance, in future research, it will be necessary to optimize the design of gradation for the sake of improving the cracking resistance

\section{Data Availability}

The data used to support the findings of this study are included within the article.

\section{Conflicts of Interest}

The authors declare that they have no conflicts of interest.

\section{Authors' Contributions}

Yan Xin and Ying Ronghua contributed equally to this paper.

\section{Acknowledgments}

The work was financially supported by the InnovationDriven Plan in Central South University (2020zzts159).

\section{References}

[1] B. Peng, L. G. Li, and G. K. Yin, "Low cement dosage stabilized crushed stone gradation composition design and performance research," Highway, vol. 6, pp. 33-36, 2018.

[2] Y. Zhang, L. Jiang, W. Zhou, Y. Feng, Z. Tan, and X. Chai, "Study of bridge-subgrade longitudinal constraint range for high-speed railway simply-supported beam bridge with CRTSII ballastless track under earthquake excitation," Construction and Building Materials, vol. 241, Article ID 118026, 2020.

[3] L. Z. Jiang and Y. T. Zhang, "Simplified calculation modeling method of multi-span bridges on high-speed railways under 
earthquake condition," Bulletin of Earthquake Engineering, vol. 18, no. 2, 2020.

[4] H. P. Li, F. Wang, and C. Li, "Analysis and research on the influence of basalt fiber on the performance of asphalt mixture," China \& Foreign Highway, vol. 18, pp. 22-33, 2016.

[5] Z. Y. Yao and Y. J. Zhang, "Performance analysis of basalt fiber asphalt stabilized macadam," Journal of Shandong University: Engineering Edition, vol. 4, pp. 69-74, 2018.

[6] B. Peng, W. Gong, and X. G. Meng, "A study on gradation design method of micro asphalt gravel middle layer mixtures," Journal of Wuhan University of Technology (Transportation Science\&Engineering), vol. 25, pp. 259-263, 2018.

[7] L. Wang and Z. G. Liu, "Cracking cause and treatment measure of semi-rigid base asphalt pavement," Journal of China\&Foreign Highway, vol. 5, pp. 84-86, 2020.

[8] J. G. Wei, Q. L. Fu, and J. D. Xu, "Effect of asphalt binder on pavement performance of asphalt macadam," Journal of Highway and Transportation Research and Development, vol. 11, pp. 1-8, 2014.

[9] D. Li, "Research on mechanical characteristics and design method of graded crushed stone material," China and Foreign Highway, vol. 19, pp. 102-106, 2017.

[10] B. Huang, X. Shu, and Y. Tang, "Comparison of semi-circular bending and indirect tensile strength tests for HMA mixtures," Advances in Pavement Engineering, vol. 81, pp. 1-12, 2019.

[11] C. Xia, S. Lv, M. B. Cabrera, X. Wang, C. Zhang, and L. You, "Unified characterizing fatigue performance of rubberized asphalt mixtures subjected to different loading modes," Journal of Cleaner Production, vol. 279, 2021.

[12] M. SheikllZadeh and S. Mahdi Hejazi, "Fiber-reinforced asphalt- concrete- a review," Construction and Building Materials, vol. 21, pp. 871-877, 2010.

[13] C. Liu, S. Lv, D. Jin, and F. Qu, "Laboratory investigation for the road performance of asphalt mixtures modified by rock asphalt/styrene butadiene rubber," Journal of Materials In Civil Engineering, vol. 10, 2020.

[14] K. F. Li, Research on the Design Method of Micro-asphalt Macadam Mix Ratio, Chang'an University, Xi'an, China, 2014.

[15] F. Y. Wang, "Research on the design method of micro-asphalt macadam mix ratio," China and Foreign Highway, vol. 3, pp. 3-10, 2014.

[16] J. Han, X. F. Yu, and D. H. Zhou, "Study on the preparation technology and performance of basalt fiber reinforced highviscosity asphalt mixture," China and Foreign Highway, vol. 58, pp. 217-220, 2015.

[17] X. J. Liu, "Research on the road performance of basalt fiber asphalt mixture," China and Foreign Highway, vol. 11, pp. 74-76, 2015.

[18] X. Qin, A. Q. Shen, and Y. C. Guo, "Experimental study on the performance of basalt fiber asphalt mortar," Journal of Building Materials, vol. 17, no. 4, 2016.

[19] H. Lu and X. N. Zhang, "application of mineral fiber asphalt mixture in long steep slope sections," China and Foreign Highway, vol. 25, pp. 84-86, 2017.

[20] Y. Y. Wang, "Research on the performance and design method of graded crushed stone base course," Master's Degree thesis, Southeast University, Nanjing, China, 2020.

[21] Z. G. Zhou, Y. Zeng, and X. K. Sun, "Research on mechanical properties of asphalt pavement cement modified graded gravel," Transportation Science and Engineering, vol. 35, pp. 84-86, 2012.
[22] B. Peng and S. J. Cao, "Study on the composition design and performance of a new type of asphalt-poor macadam," Journal of Dalian University of Technology, vol. 6, pp. 609-614, 2017.

[23] People's Communications Press, The Ministry of Transport of the People's Republic of China. Code for Design of Highway Asphalt Pavement: JTG D50-2017, People's Communications Press, Beijing, China, 2017.

[24] B. Y. Yu, M. J. Zhang, and T. W. Li, "Analysis of the micro bonding graded gravel asphalt pavement structure," Journal of Shenyang Jianzhu University (Natural Science), vol. 42, no. 1, pp. 852-860, 2013.

[25] Z. J. Zhang, "Mitigation strategies for reflection cracking in rehabilitated pavements-A synthesis," International Journal of Pavement Research and Technology, vol. 5, pp. 284-286, 2016.

[26] J. Zhou, X. L. Wang, C. Y. Zheng, and X. C. Bao, "comparison of design methods of micro-bonded asphalt macadam mix ratio," Journal of Wuhan University of Technology, vol. 36, pp. 68-70, 2017.

[27] D. G. Sun, L. Peng, and F. J. Ni, "Re-search\&application of inverted bituminous pave-ment structure in secondary road," Communica-tions Standardization, vol. 131, pp. 59-62, 2018.

[28] K. F. Liu, "Research on road performance of fiber asphalt mortar and asphalt mixture," Journal of Chongqing Jiaotong University (Natural Science Edition), vol. 98, pp. 407-410, 2019.

[29] Q. Zheng, "Basalt fiber:perfect choice ofSMA and OGFC pavement," Chin Highway, vol. 65, pp. 5-8, 2018.

[30] P. Li, Z. Wu, and K. Ma, "Cracking resistant of asphalt mixture at the low temperature based on the SCB test," Journal of Wuhan University of Technology:Transportation Science and Engineering, vol. 66, pp. 238-241, 2019.

[31] S. Amarasiri, M. Gunaratne, and S. Sarkar, "Modeling of crack depths in digital images of concrete pavements using optical reflection properties," Journal of Transportation Engineering, vol. 38, pp. 489-499, 2020. 